\title{
PENINGKATAN MANAJEMEN KINERJA MELALUI TOTAL KUALITAS MANAJEMEN, SISTEM PENGUKURAN KINERJA DAN SISTEM PENGHARGAAN PADA BALAI BESAR LOGAM DAN MESIN
}

\author{
Fifi Ainur Ramadhina ${ }^{1}$ \\ Universitas Komputer Indonesia \\ fifiaramadhina@gmail.com \\ Dewi Indriani² \\ International Women University \\ fifiaramadhina@gmail.com
}

\begin{abstract}
Abstrak - Balai Besar Logam dan Mesin merupakan balai yang berdiri berdasarkan SK direktorat Jendral Perindustrian Dasar No.48/Kpts.DD/Perdas. Dalam hal ini penulis bertujuan untuk meneliti tentang manajemen kinerja, total kualitas manajemen, sistem pengukuran kinerja serta sistem penghargaan. Lokasi penelitian ini dilakukan pada Balai Besar Logam dan Mesin. Riset ini termasuk ke dalam jenis kuantitatif dengan mengacu pada wawancara serta kuesioner. dengan menggunakan metode sampel yang terdiri dari 53 responden. penelitian ini ditunjukkan bagi pegawai PNS. Teknik pengumpulan data menggunakan kuesioner untuk menilai seberapa tinggi peningkatan manajemen kinerja. Hasil riset ini menunjukkan bahwa semua pertanyaan yang diajukan bersifat valid dan reliabel. Uji deskriptif menghasilkan bahwa keempat variabel tergolong baik, sedangkan pada uji verifikatif menghasilkan ketiga variabel secara bersamaan memiliki pengaruh yang signifikan terhadap manajemen kinerja.
\end{abstract}

Kata kunci : Manajemen Kinerja, Total kualitas Manajemen, Sistem pengukuran kinerja, Sistem penghargaan

Abstrak - Balai Besar Logam dan Mesin is a hall that is eshtablished based on the Decree of Directorate General of Basic Industry No.48/Kpts.DD/Perdas. This study is purpose for detect improving management performance through total quality management, system measurement performance and reward system. The location research at Balai Besar Logam dan Mesin. The reaserch belongs to the type of quantitative detailed with reference to interview and questionnaire. The method use is a sample, which consists 53 respondents. The subjects in this study were servants at Balai Besar Logam dan Mesin. The data gathering technique method is questionnaire is used to assess how high improvement management performance. Study result indicate that all character question are valid and reliable. Descriptive analysis show are four variables precious good. 
Verification analysis show the together variable independent have a significant effect on variable dependen.

\section{Keyword : Management Performance, TQM, Performance Measurement System, System Reward}

PENDAHULUAN

Persaingan dunia sangatlah ketat yang dimana persaingannya ditentukan oleh perekonomian dunia, suatu instansi perlulah memiliki ciri khas tersendiri yang dapat menjadi daya saing dipasar global. Semakin ketatnya persaingan dalam dunia bisnis menuntut sebuah organisasi dapat mengembangkan sumber daya manusia kerah yang lebih baik. Dengan meningkatnya SDM tersebut akan meningkatkan pula Manajemen Kinerja pada sebuah instansi yang dapat meningkatkan kualitas produk.

Berlakunya sistem

MEA menyebabkan perusahaan di setiap negara dihadapkan pada situasi perdagangan global yang memberikan banyak pilihan. Untuk dapat bertahan pada masa ini, sebuah instansi harus dapat menciptakan nilai untuk konsumen dalam kualitas yang lebih baik. Yang menjadi utamanya adalah pendekatan yang tepat dengan menerapkan Total Quality Management untuk mengembangkan kualitas pegawai yang nantinya selaras dengan peningkatan kualitas produksi. TQM merupakan cara yang dilakukan untuk menjalankan suatu usaha dengan daya saing yang lebih baik melalui perbaikan kualitas secara berkesinambungan (Tjiptono 2001 dalam I Made 2018).

Begitu pula dengan Sistem pengukuran kinerja memberikan mekanisme penting bagi pegawai yang nantinya akan diterapkan untuk menjalankan tugasnya agar mencapai tujuan dan standar kinerja. Dengan adanya sistem ini, top manajer harus mendapatkan umpan balik tentang pelaksanaan wewenang dari manajer dibawah-Nya (Nastiti, 2013)

Selain ketiga variabel diatas, sebuah instansi juga harus menerapkan suatu sistem untuk dapat memotivasi pegawai agar dapat lebih meningkatkan kinerja demi kesejahteraan sebuah instansi. Sistem yang dimaksud merupakan sistem penghargaan dimana pegawai akan mendapatkan imbalan sesuai dengan prestasi yang mereka hasilkan baik fisik maupun non fisik. Dalam penelitian (Florbela 2019) menyatakan, penerapan reward (penghargaan) memiliki hubungan yang positif dan signifikan terhadap manajemen Kinerja.

\section{Tujuan Penelitian}

- Untuk mengetahui TQM, Sistem pengukuran kinerja, Sistem penghargaan serta Manajemen kinerja

- Untuk mengetahui besarnya Manajemen Kinerja dipengaruhi TQM

- Untuk mengetahui besarnya Manajemen Kinerja dipengaruhi Sistem Pengukuran Kinerja

- Untuk mengetahui besarnya Manajemen Kinerja dipengaruhi Sistem Penghargaan

- Untuk mengetahui besarnya Manajemen Kinerja dipengaruhi secara simultan oleh TQM, Sistem pengukuran kinerja dan Sistem penghargaan. 


\section{KAJIAN LITERATUR}

\section{Total Kualitas Manajemen}

Total Kualitas Manajemen atau TQM merupakan sebuah budaya yang harus dibangun maupun ditingkatkan dan berfokus pada orang/tenaga kerja, yang bertujuan untuk meningkatkan kualitas yang nantinya akan menghasilkan value yang lebih tinggi bagi sebuah instansi. Esensi TQM harus melibatkan semua pegawai dalam meningkatkan kualitas yang akan berjalan secara berkelanjutan. Dalam penerapannya TQM janganlah diterapkan secara bersama-sama dengan sistem yang lain, dan diterapkan secara bertahap kepada pegawai.

(Tjiptono dan Diana $2003: 150$ terdapat 10 unsur utama yang dapat meningkatkan TQM :

1. Fokus terhadap konsumen

2. Ambisi kepada kualitas

3. Pendekatan yang ilmiah

4. Kesetiaan

5. Kerja sama

6. Pembetulan sistem secara berkala

7. Diklat

8. Kebebasan yang bertanggung jawab

9. Tujuan yang searah

10. Adanya pembangunan pegawai

\section{Sistem Pengukuran Kinerja}

Sistem pengukuran Kinerja ialah sebuah proses yang dilakukan sebuah instansi untuk menilai kinerja seorang pegawai demi memperbaiki pengambilan keputusan yang berlangsung (Handoko 2013). Tujuan diadakannya sistem pengukuran kinerja ialah untuk memotivasi pegawai yang lalai dalam pekerjaannya untuk memenuhi standar yang diterapkan oleh atasan ataupun juga untuk menekan perilaku yang tidak semestinya dilakukan seorang pegawai. sistem pengukuran kinerja dapat bermanfaat bagi sebuah organisasi apabila hasil yang dicapai dapat memberikan umpan balik serta membantu pegawai dalam usahanya memperbaiki kualitas.

Menurut (Mulyadi:2013) indikatorindikator dalam sistem pengukuran kinerja ialah penilaian yang berbobot, mengikut sebuah latihan serta penilaian yang dilakukan secara berkala.

\section{Sistem Penghargaan}

Sistem penghargaan merupakan suatu pemberian kepada seorang pegawai atas jasa yang telah ia lakukan atas meningkatnya value yang dihasilkan suatu perusahaan (Kurnianingsih 2000). Penghargaan dibagi ke dalam dua jenis, ada penghargaan yang berdasarkan pengalaman dan ada pula penghargaan yang berdasarkan kinerja yang dihasilkan

Adapun indikator-indikatornya adalah bobot suatu pekerjaan, jam kerja atau kedisiplinan, pendidikan seorang pegawai (Mulyadi 2007)

\section{Manajemen Kinerja}

Manajemen kinerja ialah suatu kegiatan untuk mengetahui apakah sasaran sebuah perusahaan telah tercapai secara efektif dan efisien. MK pun merupakan suatu penilaian kemampuan seorang pegawai dari hasil kerja keseluruhannya yang akan dijadikan standar untuk mencapai tujuan awal. Indikator-indikator dalam manajemen kinerja adalah baik atau buruknya output, banyak atau sedikitnya output, serta pengetahuan terhadap pekerjaan yang ia tekuni (Mulyadi 2007)

\section{METODE PENELITIAN}

Penelitian yang dilakukan menggunakan data primer atau data yang nantinya diambil dari keputusan interview 
maupun kuesioner, serta data sekunder yang penulis ambil dari beberapa buku serta jurnal yang mendukung. Jumlah populasi yang ada adalah 115 orang pegawai. pengambilan sampel sebanyak 53 responden dengan menggunakan rumus slovin. Pada setiap pertanyaan diberikan 5 buah pilihan jawaban.

Penelitian ini menggambarkan 3 (tiga) variabel bebas serta 1 (satu) variabel terikat. Data yang diperoleh dari penyebaran kuesioner ini akan dianalisis menggunakan analisis deskriptif serta analisis regresi linier berganda.

\section{HASIL DAN PEMBAHASAN}

\section{Gambaran Umum Responden}

Atas hasil kuesioner yang disebar kepada 53 responden, karakteristik responden tidak dapat penulis jabarkan secara spesifik karena itu merupakan rahasia bagi responden.

\section{Hasil Pengujian Instrumen}

Untuk mengetahui apakah kuesioner yang telah disebarkan layak atau tidak, maka penulis menguji dengan uji validitas dan reliabilitas. Pada uji validitas penulis memakai kriteria Pearson Product Memori dengan tingkat koefisien validitas lebih besar dari 0.03 . Dari 33 pertanyaan yang diajukan dalam kuesioner semuanya bernilai valid, karena koefisien validitasnya diatas 0.03. Uji reliabilitas menggunakan nilai Split Half lebih besar dari 0,7.

\section{Rekap Uji Reliabilitas}

Tabel 1. Hasil pengolahan software SPSS

\begin{tabular}{|l|c|c|l|}
\hline \multicolumn{1}{|c|}{ Variabel } & $\begin{array}{c}\text { Koefisie } \\
\mathbf{n} \\
\text { Reliabili } \\
\text { tas }\end{array}$ & $\begin{array}{c}\text { Titi } \\
\mathbf{k} \\
\text { Krit } \\
\text { is }\end{array}$ & $\begin{array}{c}\text { Kesimpu } \\
\text { lan }\end{array}$ \\
\hline $\begin{array}{l}\text { Total Kualitas } \\
\text { Manajemen (XI) }\end{array}$ & 0,907 & $\begin{array}{c}0,70 \\
0\end{array}$ & Reliabel \\
\hline $\begin{array}{l}\text { Sistem Pengukuran } \\
\text { Kinerja (X2) }\end{array}$ & 0,758 & $\begin{array}{c}0,70 \\
0\end{array}$ & Reliabel \\
\hline $\begin{array}{l}\text { Sistem } \\
\text { Penghargaan(X3) }\end{array}$ & 0,783 & $\begin{array}{c}0,70 \\
0\end{array}$ & Reliabel \\
\hline Manajemen Kinerja (Y) & 0,804 & $\begin{array}{c}0,70 \\
0\end{array}$ & Reliabel \\
\hline
\end{tabular}

Sumber: Hasil pengolahan software SPSS

\section{Analisis Deskriptif}

Pada hasil penelitian kepada 53 responden. Tabel disajikan pada tabel $1 \mathrm{di}$ bagian lampiran.

Berikut merupakan hasil pengolahan data dapat diketahui bahwanya hasil dari variabel TQM pada Balai Besar Logam dan Mesin termasuk kedalam kategori baik dengan persentase 58,97\%. Dimana indikator yang paling berpengaruh ialah komitmen jangka panjang.

Hasil pengolahan data dapat diketahui bahwa variabel sistem pengukuran kinerja pada Balai Besar Logam dan Mesin termasuk kedalam kategori baik dengan hasil persentase $69,18 \%$. Dimana indikator yang paling berpengaruh ialah penilaian yang berbobot.

Dari hasil pengolahan data dapat simpulkan bahwa variabel sistem penghargaan pada Balai Besar Logam dan Mesin kedalam kategori baik dengan persentase $70,72 \%$. Dimana indikator yang paling berpengaruh ialah wawasan pegawai.

Hasil yang diperoleh dapat diambil kesimpulan variabel manajemen kinerja 
termasuk kedalam kategori baik dengan hasil persentase $77.59 \%$. dimana indikator yang paling berpengaruh ialah kualitas kerja.

\section{Uji Asumsi Klasik}

Penelitian menggunakan analisis statistik dengan menggunakan metode regresi berganda. Model yang dihasilkan dapat dikatakan baik apabila dapat memenuhi uji asumsi klasik. Sebelum di uji lebih lanjut model ini di uji asumsi klasik yaitu uji normalitas, uji multikolineritas dan uji heteroskesdastisitas.

Pengujian normalitas menggunakan uji Kolmogorov-smirnov dengan nilai signifikan 0,05. Pada hasil uji normalitas menunjukkan nilai sig sebesar 0.446 atau lebih besar 0.05 yang artinya Ho diterima dan data tersebut berdistribusi normal.

Pengujian multikolineritas adalah untuk menguji apakah adanya hubungan linier antara variabel bebas. Penelitian ini menggunakan nilai (VIF) sebagai ukuran ada atau tidaknya multikolineritas. multikolineritas tidak akan terjadi jika VIF berada dibawah nilai 10 atau Tolerance Value lebih besar dari 0,1. Pada pengujian ini di dapatkan semua nilai VIF dibawah nilai 10 dan Tolerance Value lebih besar dari 0.1. sehingga dapat disimpulkan data tersebut tidak terjadi multikolineritas.

Uji heteroskesdasitistas dilakukan dengan uji Rank Spearman. Apabila nilai korelasinya tidak signifikan berarti tidak terjadinya pelanggaran asumsi heteroskesdastisitas. Hasil dari penelitian ini tampak bahwa nilai sig pada ketiga variabel lebih besar dari 0,05 , artinya korelasi tidak signifikan sehingga tidak terjadinya pelanggaran heteroskesdastisitas.

\section{Analisis Regresi Linier Berganda}

Pengaruh paling kuat ada pada variabel TQM, dengan nilai korelasi sebesar $30,2 \%$ dan yang paling rendah pengaruhnya terhadap manajemen kinerja adalah variabel sistem pengukuran kinerja dimana hanya memiliki nilai korelasi sebesar 5,9\%.

Dari hasil uji $F$ nilai $F$ yang didapatkan yaitu sebesar 12,166 . Dikarenakan nilai $F$ hitung lebih besar dari $F$ tabel, maka Ho ditolak. Jadi kesimpulannya bahwa ketiga variabel TQM, Sistem Pengukuran Kinerja dan Sistem Penghargaan secara bersamaan memiliki pengaruh yang signifikan terhadap Manajemen Kinerja.

\section{PENUTUP}

\section{Kesimpulan deskriptif}

Pada hasil analisis dan pembahasan pada bab sebelum-Nya maka penulis mengambil kesimpulan sebagai berikut :

- Peningkatan manajemen kinerja pada Balai Besar Logam dan Mesin tergolong baik

- Total Kualitas Manajemen pada Bali Besar Logam dan Mesin tergolong baik

- Sistem pengukuran kinerja pada Bali Besar Logam dan Mesin tergolong baik

- Sistem penghargaan pada Bali Besar Logam dan Mesin tergolong baik

\section{Kesimpulan verifikatif}

- Peningkatan manajemen kinerja dipengaruhi secara signifikan oleh total kualitas manajemen

- Peningkatan manajemen kinerja dipengaruhi signifikan oleh sistem pengukuran kinerja 
- Peningkatan manajemen kinerja dipengaruhi secara signifikan oleh sistem penghargaan

- Peningkatan manajemen kinerja secara bersama-sama dipengaruhi secara signifikan oleh TQM, Sistem pengukuran kinerja dan Sistem penghargaan

\section{Saran}

1. Balai Besar Logam dan Mesin diharapkan mampu memberikan atau menyebarluaskan informasi kepada seluruh pegawai agar tidak adanya kesalahan informasi tentang kebutuhan pelanggan yang nantinya akan menyebabkan kerugian, salah satu caranya adalah dengan menempelkan pengumuman pada papan pengumuman yang tersedia agar dapat dibaca oleh seluruh pegawai.

2. Tidak adanya jaminan atau garansi atas jasa yang ditawarkan pegawai Balai Besar Logam dan Mesin diharapkan dapat selalu lebih teliti dalam mengerjakan tugas yang dibebankan, karena jika terdapat kesalahan sedikit saja akan menyebabkan instansi mengalami kerugian.

3. Manajemen Kinerja akan berjalan baik apabila para pegawai dapat memenuhi aturan yang sudah diterapkan, para pegawai Balai Besar Logam dan Mesin diharapkan mampu datang tepat pada waktunya dan segera mengerjakan tugasnya yang telah diberikan pemimpin, serta jangan memperlama waktu istirahat agar target hari itu dapat terselesaikan dengan baik.
4. Balai besar logam dan mesin diharapkan juga dapat meningkatkan jabatan pegawai secara adil sesuai dengan prestasi yang mereka keluarkan untuk instansi tidak hanya dilihat dari seberapa lama bekerja tanpa dilihat secara adil.

\section{DAFTAR PUSTAKA}

I Made Narsa dan Rani Dwi Yunawati 2018. Pengaruh Interaksi Total Quality Management Dengan Sistem Pengkuran Kinerja dan Sistem Penghargaan Terhada Kinerja Manajerial (Studi Empiris pada PT. Telkom Divre V Surabaya). Surabaya: Jurnal A kuntansi dan Keuangan.

Monica Florbela de Araujo, Desak Ketut Sintaasih, dan I GedeRiana 2019. Peran M otivasi Dalam memediasi Pengaruh Sistem Reward T erhadap Kinerja Pegawai. Bali : E-jurnal Ekonomi dan Bisnis.

Rizky Multi Amalia dan Dwi Yuni Utami 2018. Pemberian Reward Berdasarkan Penilaian Kinerja Karyawan Dengan Metode AHP Pada PT. Anugerah Protecindo. Jakarta: Jurnal IImu Pengetahuan dan Teknologi Komputer.

Nasution, M.N. 2005. M anajemen mutu terpadu. Penerbit Ghalia Indonesia. Bogor

Handoko,N.2007.Sistem Pengendalian $M$ anajemen. Edisi Kedua, BPEE. Yogyakrta

Mulyadi.2007. Sistem Perencanaan \& pengendalian Manajemen. Selemba Empat. Jakarta 